\title{
P04.72. Towards a model for integrative medicine in the primary care of patients with chronic joint diseases and allergy
}

\author{
M Jong ${ }^{1 *}, M_{\text {Busch }}^{2}, L$ van de Vijver ${ }^{1}$, E Baars $^{1}$ \\ From International Research Congress on Integrative Medicine and Health 2012 \\ Portland, Oregon, USA. 15-18 May 2012
}

\section{Purpose}

In the Netherlands, Complementary and Alternative Medicine (CAM) is offered outside the world of mainstream medicine. Patients would benefit from an integrated model in which CAM is part of main stream medicine so that disclosure of risks, benefits of CAM and credentials of CAM practitioners are sufficiently dealt with. The aim of this 4-year research project is to develop, implement and evaluate a shared-care model of Integrative Medicine in a primary care setting for patients with chronic joint diseases and allergy.

\section{Methods}

This is the first project in the Netherlands where patient organizations, health care providers and health care insurers collaborate to achieve an integrative health-care model. The project consists of four stages; in stage 1 needs and preferences of patients were investigated. Based on this outcome, evidence in literature and clinical experiences, an integrated primary care model will be developed (stage 2). The integrated model will be piloted in two primary care centers in the Netherlands (stage 3 ) and evaluated with respect to outcome (stage 4).

\section{Results}

Stage 1: A national survey demonstrated CAM use in $41 \%$ of children with allergy (eczema, asthma) and $71 \%$ of adults with chronic joint diseases (arthrosis, rheumatoid arthritis). CAM therapies mostly used were homeopathy, manual therapies, acupuncture and naturopathy. The majority ( $74 \%$ allergy, $51 \%$ joint diseases group) did not actively communicate CAM use with

${ }^{1}$ Louis Bolk Institute, Nutrition \& Health, Driebergen, Netherlands Full list of author information is available at the end of the article their family physician. However, 79\% (allergy) and 70\% (joint diseases) of patients preferred a physician that informs, refers to and collaborates with CAM.

\section{Conclusion}

CAM use among chronically ill patients is high. Although most patients do not communicate CAM with their family physician, they have a high preference for a shared-care model in primary care. Based on these outcomes, such a model will be developed and presented at the conference.

\section{Author details}

${ }^{1}$ Louis Bolk Institute, Nutrition \& Health, Driebergen, Netherlands. ${ }^{2}$ van Praag Institute, Utrecht, Netherlands.

Published: 12 June 2012

doi:10.1186/1472-6882-12-S1-P342

Cite this article as: Jong et al:: P04.72. Towards a model for integrative medicine in the primary care of patients with chronic joint diseases and allergy. BMC Complementary and Alternative Medicine 2012 12(Suppl 1):P342.

Submit your next manuscript to BioMed Central and take full advantage of:

- Convenient online submission

- Thorough peer review

- No space constraints or color figure charges

- Immediate publication on acceptance

- Inclusion in PubMed, CAS, Scopus and Google Scholar

- Research which is freely available for redistribution

C Biomed Central c) 2012 Jong et al; licensee BioMed Central Ltd. This is an Open Access article distributed under the terms of the Creative Commons
Attribution License (http://creativecommons.org/licenses/by/2.0), which permits unrestricted use, distribution, and reproduction in any medium, provided the original work is properly cited. 